\title{
The Impact of Inaccurate Color on Customer Retention and CRM
}

\author{
Kevin R. Parker, Philip S. Nitse, and Albert S.M. Tay \\ Idaho State University, Pocatello, ID, USA
}

parkerkr@isu.edu; nitsphil@isu.edu; taysion@isu.edu

\begin{abstract}
The number of Internet purchases continues to increase, making customer relationship management even more critical in today's Internet marketplace. Keeping existing customers satisfied is much more cost effective than acquiring new customers. However, the Internet has been plagued by inaccurate color representation since the advent of e-commerce. Color inaccuracy has many negative consequences, the most important of which is customer defections. This paper communicates the findings of a survey conducted to assess consumer opinions about Internet purchases. Results indicate that consumers are aware of color inaccuracies and that their reactions will negatively impact the marketer. Over 55\% of the consumers surveyed indicate that they will not make future purchases from an online merchant that delivered an item in a color that did not match their expectations. With customer retention being one of the goals of customer relationship management, it is apparent that this issue must be acknowledged and acted upon.
\end{abstract}

Keywords: Customer relationship management (CRM), e-CRM, online customer retention, esatisfaction, online customer satisfaction, visual merchandising, product presentation, e-tailing.

\section{Introduction}

Customer relationship management (CRM) is a combination of people, processes, and technology designed to understand and manage a company's relationships with customers by focusing on relationship development and customer retention (Chen \& Popovich, 2003). Its purpose is to maximize profit by achieving an optimum balance between corporate investments and customer satisfaction. "CRM applications help organizations assess customer loyalty and profitability on measures such as repeat purchases, dollars spent, and longevity" (Chen \& Popovich, 2003, p. 673).

CRM traces its roots to relationship marketing, which is aimed at improving long run profitability by deemphasizing winning new customers and emphasizing customer retention through effective management of customer relationships (Christopher, Payne, \& Ballantyne, 1991). Relationship marketing refers "to all marketing activities directed toward establishing, developing, and main-

Material published as part of this publication, either on-line or in print, is copyrighted by the Informing Science Institute. Permission to make digital or paper copy of part or all of these works for personal or classroom use is granted without fee provided that the copies are not made or distributed for profit or commercial advantage AND that copies 1) bear this notice in full and 2) give the full citation on the first page. It is permissible to abstract these works so long as credit is given. To copy in all other cases or to republish or to post on a server or to redistribute to lists requires specific permission and payment of a fee. Contact Publisher@InformingScience.org to request redistribution permission. taining successful relational exchanges" (Morgan \& Hunt, 1994, p. 22). The management of customer relationships is valuable for the company (Morgan \& Hunt, 1994; Webster, 1992).

Dwyer, Schurr, and Oh (1987) indicate that customer relationships evolve over distinct phases that are related to the customer lifecycle. Greve and Albers (2006) identify three customer lifecycle 
phases: "Initiation", "Maintenance" and "Retention". These phases are characterized by differences in behaviors and orientations and therefore require different management relationship approaches at each phase (Srivastava, Shervani, \& Fahey, 1998).

This paper investigates Retention as it is impacted by inaccurate color representation on the web. This is accomplished by considering the complexities associated with color representation, establishing the importance of retention, discussing some of the determinants of retention such as customer satisfaction and service quality, and finally presenting the results of a study of consumers' perception of color inaccuracies on the web and the consequences for an online retailer.

\section{Color Representation as an Aspect of Informing Science}

Color representation, which is a characteristic of many channels used to convey product information (Stone, 2001), impacts the effectiveness of sender-to-client informing. In fact, inaccurate color representation on e-commerce sites can lead to misinforming, defined as providing incorrect or misleading information (Cohen, 2009). When considering e-commerce transactions from the perspective of the Informing Science Framework, the informer is the web site developer acting on behalf of the vendor, providing product information via the Internet to potential consumers. Cohen (2009) points out that the informer, information transmission and receiving media, and receiver of information exist within complex environments that greatly impact them. The upcoming discussion about Color Perception explains how various factors, like ambient lighting, can affect both the information provided as well as the information received. For example, an image of a product may be created under one set of lighting conditions, yet may be viewed under an entirely different set of lighting conditions. Further, the receiving media, in this case a color display, is affected by various factors such as the type, brand, and age of the display device on which the image is viewed, the graphics card to which the display is attached, and operating system settings for number of colors to be displayed and the resolution of the display. Finally, the entity being informed is influenced by its own psychological and physiological fragilities (Cohen, 2009). Because color is actually a sensation, colors are purely subjective, as interpreted by an individual's visual system and brain (Stone, 2001).

\section{Color Perception}

According to Stone (2001, p. 1), color perception is problematic for a variety of reasons:

- Color is subjective: It's perfectly obvious that color is an intrinsic feature of an object: Grass is green, the sky is blue, the paint on your living room wall is peach, and so on. As obvious as this may be, however, it's not so. Color is actually a sensation, just like touch. And the colors you see are purely subjective, as interpreted by your visual system and your brain.

- Lighting affects color: The color of an item - including, for example, a printout - will vary depending on the light, so it will look different under incandescent light, florescent light, and daylight, for example.

- Identical colors can be metameric pairs: Two items that are the same color under one light can be different colors under another light.

- Colors affect colors: Your perception of a color will change, depending on the colors around it, an effect called simultaneous contrast. Paint a small square of green on a blue background, and the green will have a yellowish tinge. Change the background to yellow, and the green will have a blue tinge. 
- The human eye is different from a scanner or camera: The sensors in scanners and cameras are sensitive to specific frequencies of light in different proportions than the color sensitive cones in the human eye.

- Different devices have different color gamuts: Monitors can show colors that printers can't print, and printers can print colors that monitors can't show. Cameras and scanner sensors can register colors that neither monitors nor printers can produce.

- Different devices use different color models: A color model is simply a mathematical way to represent colors. When different devices use different color models they have to translate colors from one model to another, which often introduces errors. This is a particular problem for device-dependent models, meaning models defined strictly in terms of a specific printer, monitor, scanner, or camera.

The factors noted above indicate that the adverse effects of inaccurate color representation afflict not only online shopping sites, but also more traditional means of shopping, such as retail stores and printed catalogs. The problem is actually more a matter of perception than representation, and this gives rise to the difficulty in accurately portraying the color to the consumer. Color is a sensory perception related to the frequency of the light waves being reflected from the item being viewed and not an intrinsic property of that item. This is why it is entirely possible that two items viewed in a retail store, say under fluorescent lighting, may appear to be the same color, yet when viewed outside, under natural sunlight, may appear to be different colors.

Printed catalogs introduce yet another set of lighting factors that impact the consumer's perception of a product's color. An image of the item appearing in the catalog is created under one set of lighting conditions, yet may be viewed under an entirely different set of lighting conditions. Even though the image may be painstakingly color corrected to match the original item, the catalog producer has no control over the lighting conditions under which that image will ultimately be viewed. An additional problem associated with catalogs is that the colors represented in the printing process are a close approximation produced by color composites. Most printers utilize the CMYK color model, which approximates colors in terms of the amounts of each color of ink cyan, magenta, yellow, and black. The color gamut that a printer is able to represent is much smaller than the entire range of colors that the human eye can perceive, thus the approximation is often lacking in precision.

Images of products presented on the web are subject to the same lighting issues as catalog images during their creation and viewing, as well as to a host of hardware and software factors. Some of these factors include the graphic file format in which the image is stored, the type, brand, and age of the monitor on which the image is viewed, the graphics card to which the monitor is attached, and operating system settings for number of colors to be displayed and the resolution of the display. Personal computers owned by consumers vary in image presentation due to differences in graphics cards and monitor resolution capabilities (Imation.com, 2001; Businesswire.com, 1999).

\section{Importance of Retention}

Anyone who has shopped at or even browsed e-commerce sites may have noticed that color representation is often inaccurate. Item categories that are associated with the highest sensitivity to color include cosmetics, shoes, clothing, clothing accessories, outdoor furniture, indoor furniture, home decorations, kitchen appliances, and vehicles (Krumwiede, Parker, Nitse, \& Ottaway, 2004). Inaccurate color can prompt several possible reactions from consumers. First, consumers may distrust the colors as depicted and decide against ordering, leading to a lost e-sale. Failure during the Initiation phase makes the remaining phases of CRM irrelevant. The second possible reaction to inaccurate color is that the consumer may order the product in hopes that the color matches the online depiction. If it fails to match, they may return the product, again resulting in a 
lost sale but compounded by the added costs of reverse logistics and restocking. Third, consumers may order the product and keep it even though they may not be completely satisfied. In the preceding cases the unhappy consumer may not only complain to the company about color misrepresentation but may also complain to friends. Not only does the e-tailer lose future business from the unsatisfied customer, but also from others who may be influenced by negative word-ofmouth. Further, in many cases the customer decides not to make a repeat purchase, which means that CRM has failed during the Retention phase.

Relationship management is superfluous if customers defect since there is no longer a relationship to manage. In order to retain customers, merchants must keep them satisfied. When customers are satisfied, they stay loyal longer, buy more, talk favorably about the company and its products, and cost less to service because the transactions become more routine (Kotler, 2000).

Keeping customers satisfied is cost effective, since it costs more money to lure a customer away from the competition than to keep an existing one (Kotler, 2000). Acquiring new customers can cost five times more than the costs involved in satisfying and retaining current customers (Reichheld, 1996a). Further, there appears to be a direct correlation between retention and company profitability and customer value, which is defined as a unique combination of benefits received by targeted buyers. These benefits include quality, price, convenience, on-time delivery, and both before-sale and after-sale service (Kerin, Hartley, \& Rudelius, 2007, p. 13). Also, a satisfied buyer tends to tell at least three other people about their shopping experience whereas a dissatisfied buyer tends to complain to at least nine other people. Satisfied buyers also tend to become loyal customers (Sheth, Mitral, \& Newman, 1999, p. 22).

Reichheld and Sasser (1990) found that profits in service industries increased in direct proportion to the length of a customer's relationship. Reichheld (1996a) showed that even a 5\% reduction in the customer defection rate can increase profits by $25 \%$ to $85 \%$, depending on the industry. Gupta, Lehmann, and Stuart (2004) found that a $1 \%$ improvement in retention can increase firm value by $5 \%$. A survey of more than 900 executives across different industries revealed that companies that set goals for improving customer loyalty are 60 percent more profitable than those that lack such a strategy (Saunders, 1999).

Dawkins and Reichheld (1990) also indicate that higher retention leads to higher net present value (NPV) of customers. Reichheld (1996a, 1996b) documents that a 5\% increase in customer retention results in an increase in average NPV of between $35 \%$ and $95 \%$, a statistic that is linked to significant improvements in company profitability.

To sum up, there are several benefits attached to improvements in customer retention (Reichheld \& Sasser, 1990; Reichheld \& Teal, 1996). Villanueva and Hanssens (2007) expressed these benefits in five propositions:

1. It is cheaper to retain customers than to acquire them.

2. The costs of serving long-life customers are less than those of serving new customers.

3. Long-life customers improve the reputation of the company and attract new customers through word-of-mouth advertising.

4. Long-life customers are less price sensitive than new customers and are therefore more willing to pay higher prices in some cases.

5. Long-life customers are more likely to buy more from the company, so that the company can increase their share-of-wallet through up-selling and cross-selling.

The premise that retaining existing customers is more cost effective than establishing new relationships is even truer in the changing Internet market, with its convenient availability of alternatives. Boston Consulting Group estimates indicate that it costs $\$ 6.80$ to market to existing cus- 
tomers via the web, versus $\$ 34$ to acquire a new web customer (Hildebrand, 1999). Another study found that $95 \%$ of unsatisfied customers don't complain but simply stop buying from a merchant (Technical Assistance Research Programs, 1986). Without the ability to retain customers, web marketing will fail (Reichheld \& Schefter, 2000).

One study on the impact of inaccurate color on e-marketing shows that customers often simply stop shopping at an e-commerce site if they are dissatisfied with the product that they receive (Nitse, Parker, Ottaway, \& Krumwiede, 2004). Reibstein (2002) found that product representation, which by nature must include color, was the third highest factor affecting likelihood to buy again from a particular online merchant. Industry studies show that over $50 \%$ of online shoppers would not make future purchases from an online merchant that delivered an item in a color that was not what they expected (Imation, 2001). E-commerce web sites must address the problem of inaccurate color depiction in order to reduce the number of customer defections attributed to incorrect colors (Nitse et al., 2004).

\section{Determinants of Customer Retention}

There are several determinants that are shown to impact customer retention. Customer satisfaction has been shown to be the major determinant, so it will be discussed in detail. The related issue of service quality will also be examined.

\section{Correlation between Satisfaction and Customer Retention}

Customer satisfaction has traditionally been regarded as a fundamental determinant of long-term consumer behavior (Oliver, 1997; Yi, 1990). There is extensive literature that deals with customer satisfaction and its link with customer retention. Customer satisfaction can be defined in many ways, such as the feeling of pleasure or disappointment that a customer experiences from comparing a product's perceived quality or performance as compared to his or her expectations (Kotler, 2000). If the relative quality performance falls short of expectations, the customer is dissatisfied; if it exceeds expectations, the customer is highly satisfied (Datta, Cuong, Nguyen, \& Nguyen, 2007). Wilson, Soni, and O'Keeffe (1995) indicate that customer satisfaction is assumed to lead to good things such as repeat purchases and brand loyalty (Churchill \& Suprenant, 1982), decreased costs of attracting new customers (Fornell, 1992), and lower costs of handling returns and complaints (Crosby, 1979; Garvin, 1988).

Multiple studies conclude that customer satisfaction affects customer retention (Bolton, 1998; Bolton, Kannan, \& Bramlett, 2000). The more satisfied customers are, the greater is their retention (Anderson \& Sullivan, 1993; Fornell, 1992; Payne \& Rickard, 1993). Satisfied customers are more positive towards the organization and therefore are more likely to be the loyal customers (Datta et al., 2007). A satisfied customer develops a strong relationship with the firm, and this often leads to relationship longevity (Storbacka, Strandvik, \& Grönroos, 1994). Dissatisfied customers defect; the relationship ends (Storbacka et al., 1994).

Several studies have complained that this is an oversimplification of the matter (Liljander \& Strandvik, 1993a, 1993b; Oliver, 1989; Woodruff, Cadotte, \& Jenkins, 1983; Zeithaml, Berry, \& Parasuraman, 1993). Zeithaml et al. (1993) assert that customers have a zone of tolerance that can be defined as the difference between an adequate and a desired level of service. Kennedy and Thirkell (1988) agree that customers are willing to tolerate some unfavorable incidents before expressing them in terms of overall dissatisfaction.

However, Nitse et al. (2004) found that inaccurate color leads to customer dissatisfaction and a subsequent decrease in customer retention. They point out that a majority of customers who receive a product in a color that differs from what they thought they had ordered are dissatisfied and will not make future purchases from the company. In other words, customer retention is 
Impact of Inaccurate Color on Customer Retention and CRM

negatively impacted by inaccurate color representation. Similar findings are noted by Boulding, Kalra, Staelin, and Zeithaml (1993), Richins (1983), and Scaglione (1988).

\section{Service Quality}

Service quality, or customer interaction, affects customer satisfaction (Cronin, Brady, \& Hult, 2000). The assumption is that by improving the quality of service, customers' satisfaction is improved (Storbacka et al., 1994). A critical component of service quality is delivering the product that the customer expects.

The cascade effect of service quality on satisfaction, and satisfaction on customer retention, and further customer retention on profitability has been addressed by Rust and Zahorik (1993) and Storbacka et al. (1994). Service quality is widely considered to be a key antecedent to successful customer relationships (Ennew \& Binks, 1996). The assumption found throughout service quality research is that service quality has a positive correlation with satisfaction, which in turn leads to increased retention (Storbacka et al., 1994). Improvements in customer retention can be attained through improvements in customer service quality and satisfaction (Berry \& Parasuraman, 1991; David, Ennew, \& Palmer, 1998; Zeithaml \& Bitner, 1996).

Assisting the customer in their purchase decision is one aspect of service quality. Supplying an incorrect color on the web page can mislead the customer and negatively impact service quality. In addition, delivering a product in an undesired color can also be construed as poor service quality.

\section{Research Approach}

The research question that prompted this study inquires if the inaccuracy and inconsistency of color representation using computer display equipment negatively influences a consumer's satisfaction with online purchases. This question is far too broad to be accurately accessed as stated. Therefore, the question is broken down into more specific questions addressing various parts of the online purchase decision. Not all aspects of the purchase decision are covered due to the researchers' desire to concentrate on the effects of color on the decision.

The first research question, which was prompted by experience as well as prior studies by Imation (2001) and Businesswire (1999), is "Is there a difference in the actual color of an item and the color of that item depicted on a web site, in spite of precautions to capture color accurately?"

Research into complaint behavior by Singh (1988) and Zeithaml et al. (1993) formed the foundation for the second research question: "Does the inaccuracy and inconsistency of color representation using computer display equipment increase the likelihood that a consumer will complain to an online supplier after having received a product in an unexpected color?"

The third research question, "Does the inaccuracy and inconsistency of color representation using computer display equipment increase the likelihood that a consumer will return items purchased online?" is based on the findings of Bunn (1999) with regard to reverse logistics and the return figures reported in Businesswire.com (1999).

Finally, the last research question deals with customer retention and asks, "Will consumers continue to make purchases from an online merchant that delivers an item in a color that is different than expected?"

\section{Research Methodology}

The methodology used in this study was modeled after that used by Nitse et al. (2004). This investigation involved a survey structured to investigate consumer behavior with respect to e- 
commerce, specifically respondents' assessments of color accuracy on the web. The data collection process involved a series of steps. First, e-mail and telephone interviews were utilized to establish that only a few industry leaders acknowledge there is a problem of accurate color representation on the web.

Next, a questionnaire was developed to determine if respondents have purchased products via the web, how many purchases were made in the preceding year, if they refer to a printed catalog when shopping online, what type of products they would be willing to purchase online, and which products they would not be willing to purchase online if the actual color of the product were in doubt. Respondents were also asked if they would return an item if the color differed from its representation on the Internet, if the respondent has ever actually returned a product because of incorrect color or complained about color discrepancies to the merchant, and finally if the respondent would make future purchases from an online merchant that provided an item in a color that differed from its representation.

The second stage of the study was designed to assess the level of color accuracy depicted on a monitor with an actual swatch of cloth used to generate the digital image. The digital images were developed by first scanning cloth samples of the swatches of material used in the study, then making adjustments to be sure that the images were realistic representations of the original swatches. A seven-point scale was used to capture the perceived level of accuracy of the digital image on the monitors versus the samples of the actual material used in the study.

\section{Sample and Environment}

The survey was administered to university students. Students were chosen because of the availability of a large number of subjects who represent a cross section of both experienced and inexperienced Internet shoppers. It is critical to involve experienced users since their familiarity provides them with a more realistic perspective of Internet shopping than inexperienced users. Other research dealing with e-marketing uses a similar sample (Griffith, Krampf, \& Palmer, 2001). Three hundred questionnaires were collected from the students who participated in this study.

The respondents are college students who are attending full time $(84.6 \%)$, and $71.5 \%$ were between the ages of 18 and 26 . The gender distribution was $58.4 \%$ male and $41.6 \%$ female. Other demographic breakdowns include 53.8\% single and $46.2 \%$ married students, and $63.3 \%$ have no children at home. Income level was on the lower end $(56.8 \%$ under $\$ 20,000)$, which was expected due to the age distribution and the fact that most are full-time students. The student population was deemed acceptable since the demographics of the school are not traditional, with an older than normal student body. In addition, almost half of the subjects (46.2\%) are married, and about a third of the subjects (36.7\%) have children. Thus, the sample does not suffer from homogeneity to the degree that many student samples do. Another point is that $97.8 \%$ of the students reported that they are not color blind. The $2.2 \%$ who indicated color blindness were not considered in the analysis of color accuracy.

The survey was administered in a controlled computer lab environment. The brands, types, and ages of monitors and graphics cards varied. They were intentionally not standardized in order that the environment be more representative of consumer equipment, since consumers have a wide variety of brands, types, and ages of monitors and graphics cards. It was hoped that in this way a more realistic perception of color match could be uncovered. Each respondent was given a packet of eleven folders and an instruction sheet. Each folder was numbered and contained a swatch of cloth. The respondents logged into the survey site with their unique student identification number and a password that was provided on the instruction sheet. The identification number was used to prevent the respondent from participating in the survey multiple times. The colored swatches were compared to the digital image on the screen and the accuracy of the image was rated on a 
seven-point scale, with one being very different and seven being identical. Standard demographic questions were included in the questionnaire for classification purposes.

Since the respondents used a computer-based web survey to answer the survey questions, the data is all within the appropriate ranges for the answer sets, since only acceptable answers were available to the respondents.

\section{Ramifications of Inaccurate Color}

A case has been made that a critical component of CRM is customer retention. One of the key factors of retention is satisfaction. Nitse et al. (2004) showed that customer dissatisfaction with color depicted on e-commerce sites and their monitors can lead to returns, complaints, or even to the loss of customers. This research is based on the findings of Nitse et al. (2004) and uses a similar methodology. The details of our survey are presented here. The discussion will begin with color accuracy and service quality to address the first research question.

\section{Color and Service Quality}

Since service quality can be affected by the depiction of color and the related delivery of the wrong color item, the first research question is, "Is there a difference in the actual color of an item and the color of that item depicted on a web site, in spite of precautions to capture color accurately?" To verify or refute this, respondents were asked to match actual swatches of colored material to the digital replication of them on a computer monitor. Table 1 lists the mean value of the perceived level of color accuracy for each of the eleven colors. In this seven-point scale a score of 7 is an identical match, a score of 4.0 is neutral, and anything above that indicates a close match. Of the eleven colors sampled in the survey, only graphic depictions of black and light blue were rated as consistently matching the actual swatch. Most other colors performed fairly poorly, with purples, yellows, and oranges producing the lowest ratings. Navy, grey, light green, dark green, red and rust were the other colors used in the study and they were scored as being in the middle range on color match.

Table 1: Color accuracy

Mean Value of Color Swatches

(1=very different to $7=$ identical match)

\begin{tabular}{|l|l|}
\hline Swatch\# \& Color & Mean $(\mathrm{n}=268)$ \\
\hline SW 1 -- Navy Blue & 4.31 \\
\hline SW 2 -- Black & 5.88 \\
\hline SW 3 -- Yellow & 1.96 \\
\hline SW 4 -- Grey & 4.18 \\
\hline SW 5 -- Orange & 2.29 \\
\hline SW 6 -- Light Green & 4.11 \\
\hline SW 7 -- Rust & 3.84 \\
\hline SW 8 -- Light Blue & 5.30 \\
\hline SW 9 -- Dark Green & 3.09 \\
\hline SW 10 - Purple & 1.71 \\
\hline SW 11 - Red & 3.03 \\
\hline
\end{tabular}




\section{Satisfaction}

Customer satisfaction with color can be evaluated by considering complaints or returns associated with inaccurate color. Note that both behaviors must be considered when assessing satisfaction since customers often do not complain but simply return an item or refrain from making future purchases.

\section{Complaint behavior}

The second research question inquires, "Does the inaccuracy and inconsistency of color representation using computer display equipment increase the likelihood that a consumer will complain to an online supplier after having received a product in an unexpected color?" Complaint behavior was investigated by asking if respondents would complain to the merchant if the color of the actual product differed from its representation on the Internet. Those indicating that they would complain were asked to use a four-point scale to indicate the likelihood that they would do so.

An examination of the probability that a respondent would complain due to the perceived accuracy of the color match clearly shows that for some colors the likelihood is very high. This is based on the percentage of respondents who indicated that they would complain. Generally the percentage of respondents who indicated that they would complain closely corresponds to the mean of the likelihood of complaining. Table 2 shows the percentage of respondents who indicated that they would complain (column three) and the mean from a four-point likelihood to complain scale (column four). The table shows that not only were Yellow and Purple the colors that respondents would most likely complain about, but they also had the highest likelihood mean score. Black and Light Blue had the least number of potential complaints, although the respondents who would complain about those colors have a higher likelihood of complaining than do those who would complain about several other colors, including Navy Blue and Grey.

\section{Table 2: Likelihood of Complaining}

Mean Value of Color Swatches

(1=very likely to $4=$ very unlikely)

\begin{tabular}{|l|l|l|}
\hline Swatch\# \& Color & Percent & Mean $(\mathrm{n}=268)$ \\
\hline SW 1 -- Navy Blue & 42.9 & 2.25 \\
\hline SW 2 -- Black & 8.0 & 1.76 \\
\hline SW 3 -- Yellow & 85.1 & 1.62 \\
\hline SW 4 -- Grey & 35.2 & 2.13 \\
\hline SW 5 -- Orange & 78.2 & 1.80 \\
\hline SW 6 -- Light Green & 37.5 & 1.94 \\
\hline SW 7 -- Rust & 41.0 & 1.99 \\
\hline SW 8 -- Light Blue & 9.6 & 1.96 \\
\hline SW 9 -- Dark Green & 58.2 & 1.67 \\
\hline SW 10 - Purple & 83.9 & 1.41 \\
\hline SW 11 - Red & 62.8 & 1.85 \\
\hline
\end{tabular}

Dissatisfaction and past complaint behavior are next assessed by asking respondents if they had made a purchase in the last year in which the item delivered did not adequately match the online image and if so, had they complained to the merchant. Among those who have purchased in the last year, $12.5 \%$ have complained to the online merchants (Table 3). 
Table 3: Complained to online merchant

\begin{tabular}{|l|l|l|l|l|l|}
\hline & & Freq. & $\%$ & Valid \% & Cum. \% \\
\hline Valid & No & 223 & 86.8 & 87.5 & 87.5 \\
\hline & Yes & 32 & 12.5 & 12.5 & 100.0 \\
\hline & Total & 255 & 99.2 & 100.0 & \\
\hline Missing & System & 2 & .8 & & \\
\hline Total & & 257 & 100.0 & & \\
\hline
\end{tabular}

Another item on the questionnaire asked if the respondent would complain to the merchant about color discrepancies if they received an item in which the color of the actual product differed from its representation on the Internet. Those indicating that they would complain were asked to indicate the likelihood that they would complain. Over $66 \%$ indicated that they would complain if they placed an order and the item received had a different color than was expected (Table 4). That $66 \%$ includes those who indicated a response of 5 or above on a 7 point scale, where 7 represents always. Note that these results refer to a respondent's intention or likelihood of reacting in a certain way when experiencing certain conditions.

Table 4: Likelihood of complaining

\begin{tabular}{|l|l|l|l|l|l|}
\hline & & Freq. & $\%$ & Valid \% & Cum. \% \\
\hline Valid & 1 & 5 & 1.9 & 2.0 & 2.0 \\
\hline & 2 & 17 & 6.6 & 6.6 & 8.6 \\
\hline & 3 & 21 & 8.2 & 8.2 & 16.8 \\
\hline & 4 & 44 & 17.1 & 17.2 & 34.0 \\
\hline & 6 & 75 & 29.2 & 29.3 & 63.3 \\
\hline & 7 & 46 & 17.9 & 18.0 & 81.3 \\
\hline Missing & System & 1 & 18.7 & 18.8 & 100.0 \\
\hline Total & & 257 & 100.0 & & \\
\hline
\end{tabular}

\section{Return behavior}

The third research question queries, "Does the inaccuracy and inconsistency of color representation using computer display equipment increase the likelihood that a consumer will return items purchased online?" An examination of the likelihood of returning an item based on the perceived accuracy of the color match clearly shows that for some colors the likelihood is very high, as indicated by the percentage of respondents who stated that they would return. Generally, the percentage of respondents who indicated that they would return and the mean of the likelihood of returning correspond. Table 5 shows the percentage of respondents who indicated that they would return and the mean from a four-point likelihood to return scale. Here the respondents indicated that Purple and Yellow are the colors that they would most likely return, and they also had the highest likelihood mean score. Black and Light Blue again had the least number of potential returns, although the respondents who would return items in the color black are more likely to do so 
than those returning items in several other colors. Light blue had the second lowest number of returns and the least likelihood of returning by those that would return the item.

Table 5: Likelihood of Returning Item

Mean Value of Color Swatches

(1=very likely to $4=$ very unlikely)

\begin{tabular}{|l|l|l|}
\hline Swatch\# \& Color & Percent & Mean $(\mathrm{n}=268)$ \\
\hline SW 1 -- Navy Blue & 33.1 & 1.92 \\
\hline SW 2 -- Black & 9.6 & 1.87 \\
\hline SW 3 -- Yellow & 83.1 & 1.51 \\
\hline SW 4 -- Grey & 34.5 & 2.00 \\
\hline SW 5 -- Orange & 77.4 & 1.47 \\
\hline SW 6 -- Light Green & 39.1 & 1.99 \\
\hline SW 7 -- Rust & 40.6 & 1.88 \\
\hline SW 8 -- Light Blue & 10.0 & 2.08 \\
\hline SW 9 -- Dark Green & 63.2 & 1.62 \\
\hline SW 10 - Purple & 83.9 & 1.31 \\
\hline SW 11 - Red & 65.1 & 1.83 \\
\hline
\end{tabular}

Dissatisfaction and former return behavior are next assessed by asking respondents if they had made a purchase in the last year in which the item delivered did not adequately match the online image, and if so, had they returned it to the merchant. Among those who made a purchase in the last year, $13.8 \%$ returned an item that was delivered in a color different from what was expected (Table 6).

Table 6: Returned item to online merchant

\begin{tabular}{|l|l|l|l|l|l|}
\hline & & Freq. & $\%$ & Valid \% & Cum. \% \\
\hline Valid & No & 219 & 85.2 & 86.2 & 86.2 \\
\hline & Yes & 35 & 13.6 & 13.8 & 100.0 \\
\hline & Total & 254 & 98.8 & 100.0 & \\
\hline Missing & System & 3 & 1.2 & & \\
\hline Total & & 257 & 100.0 & & \\
\hline
\end{tabular}

Another item on the questionnaire asked if the respondent would return an item if the color of the actual product differed from its representation on the Internet. Those indicating that they would return an item were asked to indicate the likelihood that they would return the item. Almost $72 \%$ indicated that they would return a product if they placed an order and the item received differed in color from what was expected (Table 7). Note that these results refer to a respondent's intention or likelihood of reacting in a certain way when experiencing certain conditions. 
Table 7: Likelihood of returning

\begin{tabular}{|l|l|l|l|l|l|}
\hline & & Freq. & $\%$ & Valid \% & Cum. \% \\
\hline Valid & 2 & 18 & 7.0 & 7.1 & 7.1 \\
\hline & 3 & 21 & 8.2 & 8.3 & 15.4 \\
\hline & 4 & 33 & 12.8 & 13.0 & 28.3 \\
\hline & 5 & 64 & 24.9 & 25.2 & 53.5 \\
\hline & 6 & 62 & 24.1 & 24.4 & 78.0 \\
\hline & 7 & 56 & 21.8 & 22.0 & 100.0 \\
\hline Missing & System & 3 & 1.2 & & \\
\hline Total & & 257 & 100.0 & & \\
\hline
\end{tabular}

While the number of customers who complain or return an item due to dissatisfaction with color may not capture those unhappy customers who do neither of the above but simply refrain from making future purchases from a company, that issue is addressed in the discussion of Table 6 below. Further, the number of respondents who expressed dissatisfaction with color misrepresentation through complaints or returns is sufficiently significant to warrant concern given that satisfaction is essential to customer retention, as discussed above.

As noted earlier, misrepresenting a product color on a web page can mislead the customer and negatively impact service quality, and delivering a product in an unsatisfactory color can also be construed as poor service quality. As pointed out, service quality reduces customer satisfaction, which in turn decreases customer retention.

\section{Retention}

The last research question asks, "Will consumers continue to make purchases from an online merchant that delivers an item in a color that is different than expected?" In order to assess customer retention issues, the questionnaire asks respondents if they would make future purchases from an online merchant that delivered an item whose color was different than what they thought they had ordered. Many respondents indicated that they neither complain nor return unsatisfactory items, but simply keep the product and refrain from making future purchases from that web site (Table 6). This finding is similar to those from Imation (2001) and Businesswire.com (1999).

With $55.5 \%$ of respondents indicating that they would not make a repeat purchase from a company that shipped an item with a color different from what was ordered and expected (those indicating a 4 or 5), it is fair to state that this is a strong level of dissatisfaction and a strong indication that customer retention could be negatively impacted. This confirms the findings of Boulding et al. (1993), Richins (1983) and Scaglione (1988). Only 12.9\%, those who indicated a response of 2 or lower on a 5 point scale where 1 is very likely, indicated that they would continue to purchase from a merchant if they had experienced a color problem (Table 8). As discussed earlier, the impact of poor customer retention can be substantial, so much so that the issue must be addressed. 
Parker, Nitse, \& Tay

Table 8: Likelihood of defecting

\begin{tabular}{|l|l|l|l|l|l|}
\hline & & Freq. & $\%$ & Valid \% & Cum. \% \\
\hline Valid & 1 & 13 & 5.1 & 5.1 & 5.1 \\
\hline & 2 & 20 & 7.8 & 7.8 & 12.9 \\
\hline & 3 & 81 & 31.5 & 31.6 & 44.5 \\
\hline & 4 & 56 & 21.8 & 21.9 & 66.4 \\
\hline & 5 & 86 & 33.5 & 33.6 & 100.0 \\
\hline Missing & System & 1 & 99.6 & 100.0 & \\
\hline Total & & 257 & 100.0 & & \\
\hline
\end{tabular}

\section{Future Research}

Is there a solution for the problem of color inaccuracy? While it is the topic of future research on our part, some commercial services are being marketed to provide accurate color. The two major forms are color correction on the client and color correction on the server. Color correction on the client is generally based on plug-ins or downloads on the user's computer.

Sonnetech, later known as E-Color and now defunct, developed a software product called Colorific that insures color consistency between an e-commerce site, the consumer's computer display, and their printer. Pantone later partnered with Sonnetech in developing the Pantone Personal Color Calibrator, which uses Sonnetech's True Internet Color technology to provide accurate Internet color for Internet shoppers.

Color correction on the server is controlled by software running on the e-commerce site and requires no plug-ins. Verifi Accurate Web Color, originally developed by Imation but purchased by Kodak Polychrome Graphics, provides a web site that guides users through a series of monitor adjustments. Users profile their computer monitor by making adjustments based on a sequence of instructions. No plug-ins or downloads are required. After completing the adjustments, the user will be able to view color-corrected images from those web sites that offer the Verifi Accurate Web Color technology. Verifi is a server-based software system that dynamically corrects images to compensate for color display variables within individual monitors.

Another attempt to address color issues was marketed by eColorChart.com, which has ceased operation. The eColorChart was touted as a low-tech solution to the color problem. The chart contained 90 color samples referenced by both name and number. Sellers could reference the eColorChart name or number on their offerings, and buyers could then reference those colors on their copy of the eColorChart to learn the product's true color.

There is a need for future research in multiple directions. With respect to technology, there are several avenues that need exploration:

- Determine the causes of color inaccuracy when images are viewed.

- Determine the causes of color inaccuracy when images are captured.

- Investigate the impact of computer displays, video cards, image file types, and other technical factors that may influence the delivery and display of color on the Internet. Apple monitors, iPhones, BlackBerry, cell phones, and different types of laptop and flat screen monitors will also be examined. 
With respect to marketing, there are several avenues that need exploration:

- Determine the significance of color accuracy on the overall purchase and post-purchase satisfaction.

- Further examine consumer complaint behavior in terms of personal values and propensity to complain.

- Determine the extent to which color inaccuracy contributes to reverse logistics costs.

- Investigate purchasing behavior in a multi-channel environment, especially in cases where a catalog is used in conjunction with the Internet web site for making the purchase decision.

\section{Conclusion}

CRM efforts must be aware of the negative impact associated with color inaccuracies on ecommerce sites. Conversations with Internet marketers during the initial stages of this undertaking revealed that many incorrectly think a vast majority of consumers are unconcerned about color accuracy when considering purchases from an e-commerce site. This naiveté can have serious ramifications on several fronts.

Increased dissatisfaction on the part of consumers leads to greater costs in both customer service and reverse logistics. For those respondents who made an online purchase in the last year, $12.5 \%$ have complained to the online merchants if they received an unsatisfactory color. Further, $13.8 \%$ of those same respondents have returned an item that was delivered in a color different from what was expected. This indicates that companies will incur additional costs if the colors of items on the web are not accurately represented.

Another area of grave concern is customer retention. Many respondents indicated that they neither complain nor return unsatisfactory items, but simply keep the product and refrain from making future purchases from that web site. A striking 55.5\% of the respondents indicated that they would not make a repeat purchase from a company that shipped an item that was in a color that was different from what was ordered and expected.

As shown previously, all of these issues have an impact on CRM efforts. Satisfaction and retention are vital to CRM. As discussed earlier, the impact of poor customer retention alone can be substantial, so much so that the issue of inaccurate color must be addressed.

This research can lead to better management of customer relationships through better understanding of the benefits and drawbacks of marketing goods via computer display. Informing Science emphasizes the imperative to bring together researchers from diverse fields to address the common problem of how best to inform clients. This research affirms that there is a need for an organization's information systems, marketing, and operations departments to work more closely together in order to improve the flow of information between the retailer, the information transmission and receiving media, and customers. As Cohen (2009, p. 5) points out, "Only a transdisciplinary approach, bringing together the expertise of all the disciplines relevant to a particular problem, offers any real hope of furthering our understanding." Transdisciplinary collaboration between departments can lead to more accurate color representation on e-commerce sites, resulting in improved customer satisfaction and ultimately allowing e-commerce to be more competitive. E-tailers who can offer better color representation on their web portal can gain a competitive advantage since they will offer a better value to online shoppers. Customer retention will improve, and CRM efforts will be able to show an even greater impact on firm success. 


\section{References}

Anderson, E. W., \& Sullivan, M. W. (1993). The antecedents and consequences of customer satisfaction for firms. Marketing Science, 12(2), 125-143.

Berry, L. L., \& Parasuraman, A. (1991). Marketing services. New York, NY: The Free Press.

Bolton, R. N. (1998). A dynamic model of the duration of the customer's relationship with a continuous service provider: The role of satisfaction. Marketing Science, 17(1), 45-65.

Bolton, R. N., Kannan, P. K., \& Bramlett, M. (2000). Implications of loyalty programs and service experiences for customer retention and value. Journal of Academy of Marketing Science, 28(1), 95-108.

Boulding, W., Kalra, A., Staelin, R., \& Zeithaml, V. A. (1993). A dynamic process model of service quality: From expectations to behavioral intentions. Journal of Marketing Research, 30(1), 7-27.

Bunn, J. (1999). Centralizing reverse logistics: How to understand if it will work for you. Consumer Markets, August, pp.11-12.

Business Wire. (1999, April 6). Study finds lack of color consistency hampers electronic commerce: Cyber dialogue reports consumer awareness of monitor color variance. Retrieved November 18, 2008, from http://findarticles.com/p/articles/mi_m0EIN/is_1999_April_6/ai_54296014

Chen, I. J., \& Popovich, K. (2003). Understanding customer relationship management (CRM): People, process and technology. Business Process Management Journal, 9(5), 672-688. Retrieved November 18, 2008, from http://www.ingentaconnect.com/content/mcb/157/2003/00000009/00000005/art00008

Christopher, M., Payne, A., \& Ballantyne, D. (1991). Relationship marketing. Oxford: ButterworthHeinemann.

Churchill, G. A., \& Suprenant, C. (1982). An investigation into the determinants of customer satisfaction. Journal of Marketing Research, 14 (November), 491-504.

Cohen, E. B. (2009). A philosophy of informing science. Informing Science: The International Journal of an Emerging Transdiscipline, 12, 1-15. Retrieved from http://inform.nu/Articles/Vol12/ISJv12p001015Cohen399.pdf

Cronin, J. J., Brady, M. K., \& Hult, G. T. M. (2000). Assessing the effects of quality, value and customer satisfaction on behavioural intentions in service environments. Journal of Retailing, 76(2), 193-218.

Crosby, P. B. (1979). Quality is free. New York, NY: McGraw-Hill.

Datta, P. R., Cuong, T., Nguyen, H. T., \& Nguyen, H. (2007). Relationship marketing and its effects on customer retention. Applied Business Research and College Teaching \& Learning Conference Proceedings, Hawaii, January 2-5.

David, B., Ennew, C. T., \& Palmer, A. (1998). Trust, ethics and relationship satisfaction. International Journal of Bank Marketing, 16(4), 170-175.

Dawkins, P. M. \& Reichheld, F. F. (1990). Customer retention as a competitive weapon. Directors and Board, 14(4), 42-47.

Dwyer, R. F., Schurr, P. H., \& Oh, S. (1987). Developing buyer-seller relationships. Journal of Marketing, $51,11-27$.

Ennew, C. T. \& Binks, M. R. (1996). The impact of service quality and service characteristics on customer retention: The small businesses and their banks in the UK. British Journal of Management, 7, 219-230.

Fornell, C. (1992). A national customer satisfaction barometer: The Swedish experience. Journal of Marketing, 56, 6-21.

Garvin, D. A. (1988). Managing quality: The strategic and competitive edge. New York, NY: The Free Press.

Greve, G., \& Albers, S. (2006). Determinants of performance in customer relationship management Assessing the technology usage-performance link. Proceedings of the 39th Hawaii International Con- 
Impact of Inaccurate Color on Customer Retention and CRM

ference on System Sciences, 6, 111b. Retrieved November 18, 2008, from http://csdl2.computer.org/comp/proceedings/hicss/2006/2507/06/250760111b.pdf

Griffith, D. A., Krampf, R. F., \& Palmer, J. W. (2001). The role of interface in electronic commerce: Consumer involvement with print versus online catalogs. International Journal of Electronic Commerce, 5(4), 135-153.

Gupta, S., Lehmann, D. R., \& Stuart, J. A. (2004). Valuing customers. Journal of Marketing Research, 41(1), 7-18.

Hildebrand, C. (1999). One to a customer. CIO Magazine, 12.

Imation. (2001). Imation tames unruly web color with Verifi technology. Retrieved November 18, 2008, from http://findarticles.com/p/articles/mi_m0EIN/is_ai_71679476

Kennedy, J. R. \& Thirkell, P. C. (1988). An extended perspective on the antecedents of satisfaction. Journal of Consumer Satisfaction, Dissatisfaction and Complaining Behaviour, 1, 2-9.

Kerin, R. A., Hartley, S. W., \& Rudelius, W. (2007). Marketing: The core. Boston: McGraw-Hill Irwin.

Kotler, P. (2000). Marketing management. Upper Saddle River, New Jersey: Prentice Hall.

Krumwiede, D., Parker, K. R., Nitse, P. S., \& Ottaway, T. A. (2004). Customer sensitivity to electronically reproduced color products: Its effect on the operation of return goods. Distribution Business Management Association Annual Conference Proceedings (pp. 1-9), Chicago, May 18-20.

Liljander, V., \& Strandvik, T. (1993a). Different comparison standards as determinants of service quality. Journal of Consumer Satisfaction, Dissatisfaction and Complaining Behaviour, 6, 118-132.

Liljander, V., \& Strandvik, T. (1993b). Estimating zones of tolerance in perceived service quality. International Journal of Service Industry Management, 4(2), 6-28.

Morgan, R. M., \& Hunt, S. D. (1994). The commitment-trust theory of relationship marketing. Journal of Marketing, 58(3), 20-38.

Nitse, P. S., Parker, K. R., Ottaway, T. A., \& Krumwiede, D. W. (2004). The impact of color in the ecommerce marketing of fashions: An exploratory study. European Journal of Marketing, 38(7/8), 898915.

Oliver, R. L. (1989). Processing of the satisfaction response in consumption: A suggested framework and research propositions. Journal of Consumer Satisfaction, Dissatisfaction and Complaining Behaviour, $2,1-16$.

Oliver, R. L. (1997). Satisfaction: A behavioural perspective on the customer. New York, NY: McGrawHill.

Payne, A., \& Rickard, J. (1993). Relationship marketing, customer retention and service firm profitability. Cranfield Business School, Cranfield, Bedford.

Reibstein, D. J. (2002). What attracts customers to online stores, and what keeps them coming back? Journal of the Academy of Marketing Science, 30(4), 465-473.

Reichheld, F .F. (1996a). The loyalty effect. Boston, MA: Harvard Business School Press.

Reichheld, F. F. (1996b). Learning from customer defections. Harvard Business Review, 74(2), 56-69.

Reichheld, F. F., \& Sasser, W. E. (1990). Zero defections: Quality comes to services. Harvard Business Review, 68(5), 105-111.

Reichheld, F. F., \& Schefter, P. (2000). E-loyalty: Your secret weapon on the Web. Harvard Business Review, 78(4), 105-114.

Reichheld, F. F., \& Teal, T. (1996). The loyalty effect the hidden force behind growth, profits, and lasting value. Boston, Mass: Harvard Business School Press. 
Richins, M. (1983). Negative word-of-mouth by dissatisfied consumers: A pilot study. Journal of Marketing, 47(Winter), 68-78.

Rust, R. T, \& Zahorik, A. J. (1993). Customer satisfaction, customer retention, and market share. Journal of Retailing, 69(2), 193-215.

Saunders, J. (1999). Manufacturers build on CRM. Computing Canada, 25(32), 17-18.

Scaglione, F. (1988). Two-way communication: Tapping into gripes and profits. Management Review, 77, 51-53.

Sheth, J. N., Mitral, B., \& Newman, B. (1999). Consumer behavior. Fort Worth: Dryden Press.

Singh, J. (1988). Consumer complaint intentions and behavior: Definitional and taxonomical issues. Journal of Marketing, 52, 93-107.

Srivastava, R. K., Shervani, T. A., \& Fahey, L. (1998). Market-based assets and shareholder value: A framework for analysis. Journal of Marketing, 62(1), 2-18.

Stone, M. D. (2001, June 11). Color matching: Color (mis)matching, and why colors are matching better than ever. ExtremeTech. Retrieved November 18, 2008, from http://www.extremetech.com/article2/0,2845,15467,00.asp

Storbacka, K., Strandvik, T., \& Grönroos, C. (1994). Managing customer relationships for profit: The dynamics of relationship quality. International Journal of Service Industry Management, 5(5), 21-38. Retrieved November 18, 2008, from http://www.ingentaconnect.com/content/mcb/085/1994/00000005/00000005/art00002

Technical Assistance Research Programs. (1986). US Office of Consumer Affairs study on complaint handling in America.

Villanueva, J., \& Hanssens, D. M. (2007). Customer equity: Measurement, management and research opportunities. Foundations and Trends in Marketing, 1(1), 1-95. Retrieved November 18, 2008, from http://www.nowpublishers.com/getpdf.aspx?doi=1700000002\&product=MKT

Webster, F., Jr. (1992). The changing role of marketing in the corporation. Journal of Marketing, 56(4), 117.

Wilson, D. T., Soni, P. K., \& O'Keeffe, M. (1995). Modeling customer retention as a relationship problem. Report No. 13-1995, Institute for the Study of Business Markets, The Pennsylvania State University, University Park, PA. Retrieved November 18, 2008, from http://www.smeal.psu.edu/isbm/database/documents/wp95/13-1995.pdf

Woodruff, R. B., Cadotte, E. R., \& Jenkins, R. L. (1983). Modeling consumer satisfaction processes using experience-based norms. Journal of Marketing Research, 20, 296-304.

Yi, Y. (1990). A critical review of consumer satisfaction. In V. A. Zeithaml (Ed.), Review in marketing (pp. 68-123). Chicago, IL: American Marketing Association.

Zeithaml, V. A., Berry, L., \& Parasuraman, A. (1993). The nature and determinants of customer expectations of service. Journal of the Academy of Marketing Science, 21(1), 1-11.

Zeithaml, V. A. \& Bitner, M. J. (1996). Services marketing. New York, NY: McGraw-Hill. 


\section{Biographies}

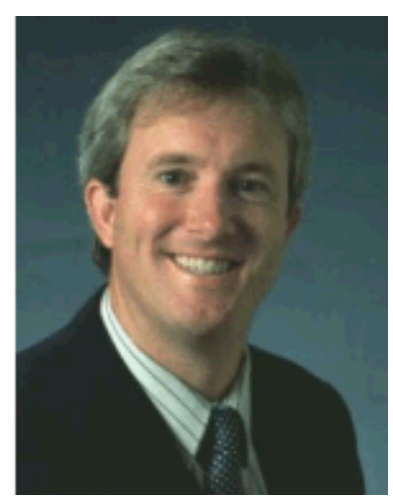

Dr. Kevin R. Parker is a Professor of Computer Information Systems at Idaho State University. He has taught both computer science and information systems courses over the course of his eighteen years in academia. Dr. Parker's research interests include e-commerce marketing, competitive intelligence, knowledge management, the Semantic Web, and information assurance. He has published in such journals as Journal of Information Technology Education, Journal of Information Systems Education, and Communications of the AIS. Dr. Parker's teaching interests include web development technologies, programming languages, data structures, and database management systems. Dr. Parker holds a B.A. in Computer Science from the University of Texas at Austin (1982), an M.S. in Computer Science from Texas Tech University (1991), and a Ph.D. in Management Information Systems from Texas Tech University (1995). Before entering academia Dr. Parker was a programmer/analyst with Conoco, Inc.

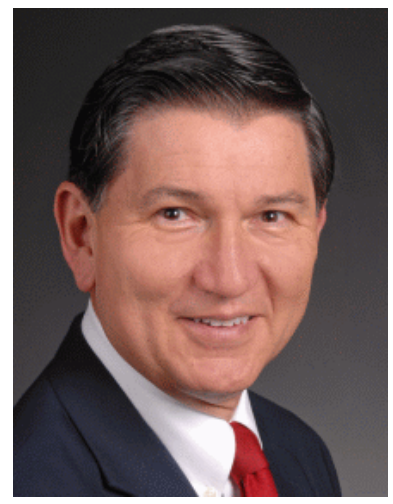

Dr. Philip S. Nitse is a Professor of Marketing at Idaho State University. His areas of research interest include competitive intelligence, knowledge management, healthcare marketing, and marketing management. He has been published in the European Journal of Marketing, Competitive Intelligence Review, Marketing Intelligence and Planning, Journal of Health Care Marketing, Journal of Direct Marketing, and Advances in Marketing. He has a B.S. in Marketing from Arizona State University, and an M.B.A. and a Ph.D. in Marketing from the University of Memphis. In addition, he has over 18 years of sales and sales management experience with organizations such as Carrier Air Conditioning, Georgia Pacific, Mass Merchandisers, and VR Business Brokers.

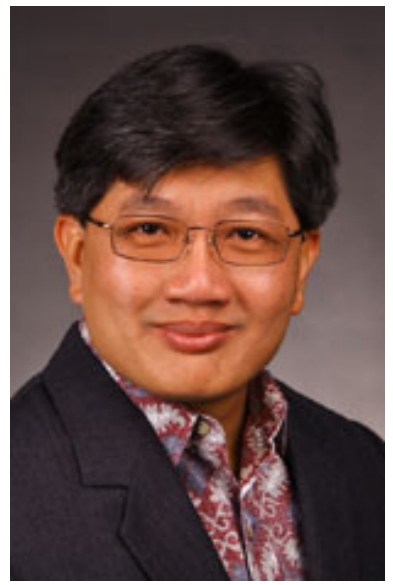

Dr. Albert Tay is an Assistant Professor of Computer Information Systems at Idaho State University. His areas of research interest include Global Information Systems, Organizational Impact of IT, Software Development and Support, and Technology Adoption. His research has been presented in academic conferences such as HICCS, AMCIS, and NACRA and has appeared in journals such as Journal of Issues in Informing Science and Information Technology and Business System Journal. He has a B.S. in Information Systems from Brigham Young University-Hawaii (1992), a M.S. in Decision and Information Systems from Arizona State University (1993), and a Ph.D. in Communication and Information Sciences from University of Hawaii at Manoa (2006). Dr. Tay has over six years of IT management experience with organizations such as Adaptec Inc, Applied Materials Inc., and Koeneman Capital Management. 